\title{
0 Que Muda Quando se Expande o Assalariamento (E Em Que o Debate da Sociologia Pode nos Ajudar a Compreendê-10)?*
}

\section{Nadya Araujo Guimarães}

Professora titular do Departamento de Sociologia da Universidade de São Paulo (USP) e pesquisadora do CNPq associada ao Centro de Estudos da Metrópole. São Paulo, Brasil (e-mail: nadya@usp.br)

\footnotetext{
$\mathrm{O}$
} vínculo formal de trabalho - comumente designado como "trabalho fichado", "trabalho registrado" ou "trabalho com carteira assinada" -, possui, entre nós, brasileiros, uma vigência simbólica que nem de longe tem sido compatível com o seu peso histórico na aritmética das formas de relação de trabalho.

Evidências desse seu valor normativo podem ser percebidas por meio de distintas pistas que atiçam o olhar do analista. Assim, de há muito sabemos que o valor mínimo da remuneração estabelecida para o trabalho formalmente contratado, o salário-mínimo, se constitui num balizador, a organizar o modo como se institucionalizam e propagam, na

\footnotetext{
* Este texto se beneficia de achados do projeto "Redes sociais e obtenção de trabalho: os mecanismos não mercantis na operação do mercado de trabalho", que tem contado com o suporte da Fundação de Amparo à Pesquisa do Estado de São Paulo (Fapesp) (Programa CEPID (Centros de Pesquisa, Inovação e Difusão), processo nº 1998/14342-9 e Programa (Instituto Nacional de Ciência e Tecnologia), processo 2008/57843-1) e do Conselho Nacional de Desenvolvimento Científico e Tecnológico (CNPq) (Edital Universal, processo 481268/2004-9 e Programa INCT proc. 573864/2008-0). No preparo dos dados recebi o apoio de Jonas Bicev e Paulo Henrique da Silva. As ideias aqui expressas são devedoras do debate com os membros da minha equipe de pesquisa, notadamente Flavia Consoni, Wagner Bessa e Jonas Bicev. Os seminários com colegas do Centro de Estudos da Metrópole e do Centro Brasileiro de Análise e Planejamento alimentaram possíveis saídas interpretativas e novas interrogações. Agradeço, igualmente, os comentários de Luiz Antonio Machado da Silva, de Álvaro Comin e dos pareceristas anônonimos da revista DADOS, cujas sugestões em muito contribuíram para enriquecer e precisar o meu argumento inicial.
}

DADOS - Revista de Ciências Sociais, Rio de Janeiro, vol. 54, nº 4, 2011, pp. 533 a 567. 
economia, as regras de remuneração pelo trabalho (Oliveira, 1972). Mas é certo também que "o trabalho com carteira" e o salário-mínimo que a ele se associa estabeleceram, como bem o notou Noronha (2003), a métrica para o que seria subjetivamente considerado ideal e/ou justo.

[...] as noções populares de contrato de trabalho "ideal" são bastante influenciadas pela legislação do trabalho. Os cidadãos dos centros urbanos têm como parâmetro do ideal o contrato em carteira; alternativamente, e com mais intensidade sonha-se com um trabalho autônomo, mas quase nunca com um contrato de trabalho "informal". (p. 122)

Se é assim, um curioso paradoxo parece caracterizar a nossa sociedade: em que pese a construção de uma norma contratual tenha sido, no Brasil, um processo jurídico-político de consolidação relativamente recente, e conquanto sua universalização no jogo econômico do mercado de trabalho jamais tenha se verificado, a relação de assalariamento formal regido por contrato por tempo indeterminado adquiriu notável vigência simbólica. Nesse sentido, numa discussão empírica sobre a sua reconfiguração, caberia retomar, ainda que brevemente e em grandes linhas, o modo como a Sociologia brasileira equacionou esse paradoxo.

Assim, na primeira parte deste texto situarei, articulando, respostas produzidas em dois contextos do debate intelectual do nosso campo: o dos anos 1960-1970, quando o pensamento sociológico encarou o desafio de entender a formação da sociedade industrial no Brasil, apurando a lente para focalizar o perfil e as atitudes da classe trabalhadora que se concentrara nos grandes espaços urbanos desde o crescimento industrial dos anos 1950; e o contexto dos anos 1980-2000 quando instabilidade econômica, crises de crescimento e abertura à competição internacional produziram intensa reestruturação micro-organizacional e das cadeias produtivas, com efeitos devastadores sobre o emprego, que desafiaram intérpretes a novamente pensar sobre as representações a respeito do trabalho, do contrato e, agora também, do desemprego. Ou seja, procurarei, nesta primeira parte, entender como em contextos de expansão de oportunidades, no primeiro caso, e de contração dessas, no segundo, o lugar do trabalho assalariado, na estrutura e nas representações, foi estabelecido por nossa Sociologia ${ }^{1}$.

Isso posto, na segunda parte, tratarei de explorar aquilo que sugiro, já desde o título do artigo, como a novidade presente: quando se expande o assalariamento, e isso vem ocorrendo de maneira sistemática desde 
meados da década passada, que novos desafios à interpretação sociológica se estabelecem?

Com efeito, os indícios de mudanças recentes no nosso mercado de trabalho apontam para a emergência de uma combinação singular: a retomada do crescimento do contingente dos trabalhadores formais tem sido concomitante com o incremento, ainda mais célere, de uma modalidade particular da relação de trabalho assalariado, a qual denominarei doravante "trabalho intermediado".

Trata-se de uma relação social em que a figura de um intermediador se interpõe entre o trabalhador formalmente assalariado e o patrão para o qual trabalha. Uma tríade, ao invés da díade, que se constituiu na forma sob a qual nos acostumamos a exprimir a relação contratual de trabalho (se mais não fosse, por ser o formato mais frequente no ambiente dos empregos registrados). Todavia, a mera existência de um tertius, um terceiro vértice nesse triângulo de forças em relação, não nos autoriza a subsumi-la na categoria "trabalho terceirizado"; e isso por duas razões. Primeiramente, porque o intermediador pode agenciar e locar trabalhadores sob outras relações de trabalho como o "temporário", ou mesmo o "estagiário", formas que, ao lado do "terceirizado", estão igualmente amparadas no marco regulatório dos vínculos formais no Brasil. Em segundo lugar, porque o intermediador pode não ser o contratante, mas apenas agenciar a contratação, sendo pago, por tal serviço, pela empresa (futura) usuária; vale dizer, conquanto não estabeleça o vínculo, ele o viabiliza, agenciando e/ ou selecionando o trabalhador, numa relação significativa do ponto de vista de uma sociologia do funcionamento do mercado de trabalho. Não sem razão a classificação nacional das atividades econômicas (CNAE) reconhece e nomeia a figura da "empresa de seleção, agenciamento e locação de pessoal", como constituindo um ramo de negócio específico dentre aqueles "serviços prestados [por empresas] principalmente a [outras] empresas" (que comumente denominamos, de maneira algo aligeirada, "empresas terceirizadas") $)^{2}$.

Assim sendo, quando o assalariamento registrado se expande, e passa a abarcar trabalhadores antes ocupados sob formas de trabalho autônomo ou ocupados sem contrato ou mesmo desempregados, ele simultaneamente se reconfigura. Descrever tal reconfiguração, mapeando sua atual complexidade e identificando os impactos desta para uma 
compreensão do modo como o assalariamento se (re)constrói entre nós, material e simbolicamente, é o alvo maior deste texto.

As evidências em que sustentarei o meu raciocínio, apresentadas ao longo da segunda e terceira partes, foram extraídas de duas fontes principais. Os microdados do "módulo do trabalhador" da RAIS (Relação Anual de Informações Sociais), verdadeiro censo do mercado formal de trabalho, colhido na forma de cadastro administrativo compulsório pelo Ministério do Trabalho e Emprego, serviram para documentar a mudança verificada entre 1994 e 2009, atestando a escala nacional do fenômeno. Da RAIS, em sua versão longitudinal (Rais-Migra), foi também extraída uma amostra especial que acompanha, na forma de um painel, o percurso ocupacional de cerca de 143.000 trabalhadores, aleatoriamente sorteados do universo dos formalmente ocupados através das "empresas de seleção, agenciamento e locação" localizadas na Região Metropolitana de São Paulo, principal aglomerado de empregos intermediados do país; tal painel permitiu identificar, na segunda parte do texto, quem são esses trabalhadores e como chegam, e/ou saem, do mundo dos empregos intermediados.

Já os microdados da PAEP (Pesquisa da Atividade Econômica Paulista, versão 2002), produzidos pela Fundação SEADE, ao abarcarem amostra representativa (inclusive para os serviços) do universo das empresas estabelecidas naquele Estado, em 2001, permitiram observar um outro ângulo dessa complexa tríade. Eles facultaram uma detalhada investigação, cujos resultados apresento na terceira parte do texto, sobre os elos estabelecidos entre empresas de intermediação e empresas usuárias de trabalhadores intermediados. São achados desafiantes e, arrisco dizer, únicos, dada a especificidade desse cuidadoso levantamento, inexistente para o Brasil como um todo.

Finalizo o texto procurando alinhavar uma conclusão, cuja linha geral antecipo aqui. Desde a segunda metade dos anos 2000 tem se observado, no Brasil, uma notável recuperação do emprego formal. Nesse crescimento não apenas se espelham incrementos em quantitativos, mas se inscreve a importância de outra forma de relação entre empregado e empregador, a do trabalho intermediado. Analisando-o de maneira mais detida é possível reconhecer não apenas a difusão de um outro modo de gestão do recrutamento e dos contratos de trabalho, mas vê-se igualmente a emergência de um pujante segmento de negócios - 
o da intermediação - que se consolida na economia brasileira a partir das novas formas de articulação entre firmas que passam a ter lugar.

Qual o desafio que isso deixa para a interpretação sociológica? Sugiro que a heterogeneidade - antes estabelecida entre os que estavam e os que não estavam abarcados pelos vínculos formais (ou, quando muito, entre os que estavam duradouramente insertos no trabalho registrado e aqueles que transitavam entre modalidades de trabalho ou mesmo entre o trabalho e o desemprego) - se consolida ao interior do universo das formas de trabalho contratualmente pactadas. Nesse sentido, o valor simbólico do trabalho registrado, da carteira de trabalho e mesmo a cesta de direitos que se associam à formalização do vínculo de emprego já não são unívocos. Mais importante ainda, tal diversidade cresce na medida em que se expandem as oportunidades de emprego, além de que alcança de maneira diversa segmentos dos trabalhadores. Difícil reduzi-la a uma palavra mágica, a "precarização" (quase um anátema, quando o que nos desafia é conceituar), haja vista a complexidade dos efeitos da expansão do trabalho intermediado sobre os percursos ocupacionais. Necessário escrutinar o que essa nova realidade deixa para as representações sobre o trabalho, especialmente para os que viveram o risco do desemprego ou da busca mal-sucedida do primeiro emprego duradouro. Mas, impossível renunciar ao desafio de perscrutar, na reconfiguração do valor simbólico do "trabalho formal" (tornado multiforme), o "espírito" desse novo capitalismo que (e ironicamente) ganha musculatura e toma corpo justamente quando chegam ao poder aqueles que haviam sido os arautos da crítica às novas relações contratuais tecidas no âmbito do trabalho.

\section{E SE 0 ATÍPICO SE FAZ NORMA? SOCIABILIDADE E REPRESENTAÇÕES SOB FORMAS PARTICULARES DE EMPREGO E DE REGULAÇÃO DA RELAÇÃO DE TRABALHO}

Ampla literatura sociológica se encarregou de explorar a morfologia e os determinantes da particular heterogeneidade que caracterizaria o mercado brasileiro de trabalho. Seus achados, adensados ao longo dos cinquenta últimos anos, deixaram pistas instigantes com respeito ao tema que move a presente reflexão. Senão, vejamos.

O esforço interpretativo estabeleceu-se a partir de um diálogo intenso tanto com as teorias da modernização, quanto com as teorias da dependência (em seus diversos matizes). Assim talhada, a nossa sociologia 
dos mercados de trabalho emergiu nas franjas de um amplo campo temático, cujas bases se assentavam na urgência de entender os elos entre mudança social, estrutura de classes e relações de trabalho ${ }^{3}$.

Desafiava-os explicar a particularidade de mercados de trabalho que, sendo capitalistas, não generalizavam a norma capitalista de emprego: uma relação social que submeteria duradouramente os seus trabalhadores a um mesmo vínculo empregatício, tecido no coração da atividade econômica capitalista, de modo que o mercado se tornasse, e de modo inescapável, o espaço onde esses indivíduos encontrariam as condições mínimas para a sua sobrevivência. Por isso mesmo, interesses, identidades (e, por consequência, conflitos e mudança) se nutririam dessas relações; seriam economicamente informados, porque tecidos no (e através do) trabalho, o qual resultaria contratualmente transformado em mais uma mercadoria. Esse era o paradoxo que lhes parecia necessário enfrentar: o de entender uma ordem social cuja dinâmica da economia passara a se assentar em bases capitalistas, mas à qual faltavam atores sociais típicos das formações históricas que, sob essas bases, antes se haviam organizado.

A reflexão em torno da categoria "marginalidade" veio a calhar como solução interpretativa e agitou, por isso mesmo, os meios intelectuais latino-americanos desde os meados dos anos de 1960. Ali se oferecia uma teoria sociológica dessa particularidade histórica que era ao mesmo tempo uma teoria do desenvolvimento e do mercado de trabalho. Significativamente, e como um subproduto da diáspora intelectual promovida pelo regime militar, os principais autores brasileiros foram envolvidos pela necessidade de pensar o seu país no contexto da história e das transformações em curso na América Latina.

Destaque para os primeiros textos do peruano Anibal Quijano (1966, 1967 e 1973). Quase que simultaneamente a esses escritos, em 1969, surge outro artigo, também seminal e (como os de Quijano) igualmente veiculado no meio intelectual chileno, até então acolhedor das distintas diásporas intelectuais que tinham lugar no Continente. De autoria do argentino Jose Luis Nun (1969), nele se defende a pertinência de uma nova categoria, a de "massa marginal". Numa forma mais acabada frente à que esgrimira dois anos antes (Nun et alii, 1967), propunha que tal heterogeneidade refletiria a especificidade dos processos de produção da superpopulação relativa em países periféricos, sob o capitalismo monopolista. Nessas particulares condições históricas, parte 
da população excedente deixaria de cumprir a função de exército de trabalhadores de reserva, tal como preconizara Marx, ao analisar a dinâmica do mercado de trabalho sob o capitalismo concorrencial ${ }^{4}$.

Esse era, de resto, um fenômeno particularmente visível nas metrópoles em formação, onde pulsava a dinâmica dos investimentos industriais e para onde se deslocavam contingentes demográficos significativos. Entre os estudiosos da urbanização brasileira, tema desafiador dos intérpretes das mudanças em curso no Brasil dos anos de 1960 e 1970, a problemática da assim chamada "marginalidade urbana" se estabeleceu de maneira sólida, tornando-se central à agenda de pesquisa. Havíamos abandonado as formulações a respeito do caráter "sociopático" do nosso processo de crescimento urbano (Pereira, 1965). Os escritos de Luiz Antonio Machado da Silva (1971), Francisco Oliveira (1972), Manuel Berlinck (1975), Lucio Kowarick (1975) e Vilmar Faria (1976) são exemplos de como se debruçava sobre o tema o melhor da nossa inteligenzia.

A crítica à razão dualista (Oliveira, 1972), que dava sustento às teorias funcionalistas da marginalidade, nutriu-se do esforço por evidenciar como a reprodução das formas de relações de trabalho, então denominadas "não tipicamente capitalistas", era parte constitutiva das necessidades do desenvolvimento do capital, para usarmos o linguajar daquele momento; ou, como as formas não capitalistas de produção e de trabalho eram funcionais (para usarmos outra categoria que melhor evidencia a lógica de argumentação) à reprodução do capital (Kowarick, 1975; Berlinck, 1975; Prandi, 1978). Esses estudos documentaram não somente a heterogeneidade, mas a instabilidade da inserção ocupacional dos indivíduos, deixando assente, e de modo cabal, que o processo de transformação que nossos países experimentavam estava longe de se ajustar às hipóteses providas pelas teorias (lineares) da modernização.

A par disso, e no bojo do mesmo movimento intelectual, as análises sobre condições de reprodução da classe trabalhadora também desafiavam teorizações em voga no mainstream da sociologia acadêmica de então, pondo em xeque a crença de que o mercado devesse ser o exclusivo mecanismo de alocação de recursos e de distribuição social. Ao contrário, elas destacavam como outras instituições - a família, os grupos de vizinhança e as redes de sociabilidade - cumpriam papel primordial no entendimento das condições de vida e das formas de inser- 
ção no trabalho. Estas, via de regra, se equacionavam tendo o grupo familiar como arena de construção de estratégias em face da pobreza, sobretudo pela via da inserção ocupacional de seus membros (Fausto Neto, 1982; Bilac, 1978).

Nesse sentido, essas pesquisas convergiam para os achados de estudos precedentes, conduzidos entre os anos de 1950 e 1960, dentre os quais se notabilizaram os trabalhos de Juarez Brandão Lopes (1964) e Leôncio Martins Rodrigues (1970). Eles haviam se debruçado sobre o processo de constituição de um mercado nacional de trabalho. Naquele momento, as estratégias individuais, mormente expressas na migração para os grandes centros industriais, em seu movimento pendular de ir e vir, deixavam entrever a importância dos elos com os locais de origem, os refluxos da atividade econômica no local de acolhida e, nesse sentido, a convivência, em sua pluralidade, dos loci (e a fortiori, dos mercados) onde se jogava a sobrevivência. Os projetos de vida desses migrantes, mais das vezes precariamente integrados aos centros urbanos para os quais se deslocavam, eram movidos por um alvo, o da obtenção do trabalho assalariado ("fichado"), cujos direitos estavam assegurados àqueles em ocupações industriais e dos serviços; direitos esses que inexistiam, até então, no meio rural.

Entretanto, para acompanharmos como foi sendo progressivamente formulada a questão que move o interesse deste texto, é necessário avançar um pouco mais no entendimento dos elos entre, por um lado, $\mathrm{o}$ processo de constituição do mercado de trabalho e, por outro, as formas de legitimação política da ordem capitalista no Brasil.

Para tal, são imprescindíveis as interpretações avançadas por Luiz Antonio Machado da Silva (1971 e 1991, numa nova reflexão à luz do argumento original) e Wanderley Guilherme dos Santos (1979). Seminais para a construção de uma nova interpretação da sociedade brasileira, eles documentaram que o modo de construção da cidadania na nossa República era indissociável do processo de produção e regulação das relações de trabalho. Suas ideias são, por isso mesmo, cruciais para se deslindar o mistério da poderosa vigência simbólica de uma norma salarial cuja implantação real era frágil e se fazia de modo progressivo, desafiada pelas crises e refluxos da atividade econômica, nacional e internacional.

Machado da Silva desenvolveu um argumento simples e atraente. A seu juízo, já desde os anos 1930, parte significativa da economia brasi- 
leira estava monetizada; donde a pressão para que os indivíduos buscassem no mercado de consumo a satisfação para as suas necessidades. Por isso mesmo, estavam premidos a encontrar no mercado de trabalho a renda requerida para agirem enquanto compradores, reproduzindo-se e à sua família.

Entretanto, continua Machado, havia um descompasso entre tal movimento e a construção institucional do mercado de trabalho entre nós. Vale dizer, o processo de regulação das condições de oferta e uso do trabalho, um processo eminentemente político e historicamente capitaneado pelo Estado, não se fizera aqui do mesmo modo que alhures, "orgânico e minimamente disciplinado" (e uso termos do autor). Nessas condições, arguiu Machado, havia uma coincidência entre "população" e "população economicamente ativa", o que lhe permite explicar a oferta ilimitada de trabalho (ilimitada porque desregulada, a seu ver), ou, o que vem a ser o mesmo, a existência de um mercado sem barreiras de entrada (como com frequência a economia caracterizava, à época, a operação do chamado "mercado informal").

[...] nenhum atributo ou condição (idade, sexo, educação etc.) veio a se constituir como barreira clara e universal à entrada no mercado. Por outro lado, condições para a saída do mercado também não foram estabelecidas e nem institucionalmente respaldadas (seguro desemprego, previdência etc.) por meio de regras claras e universais ou, quando existiam, não eram acessíveis. (Machado da Silva, 1991:3)

Os problemas de legitimidade resultantes da ausência de uma efetiva regulação do trabalho teriam sido contornados por meio de dois mecanismos sociais. Por um lado, pela imposição do assalariamento mediante a combinação entre formas de repressão aberta, aplicadas de maneira tópica, e o assistencialismo, público e privado ${ }^{5}$. Por outro lado, pela adoção de procedimentos e relações sociais que garantiam acesso (restrito) aos direitos da cidadania a uma parte, apenas, dos trabalhadores (partícipes do "núcleo duro" da organização econômica) - um processo que Wanderley Guilherme dos Santos (1979) conceituou como de uma "cidadania regulada", também tratado como "cidadania ocupacional", dois conceitos que remetem ao caráter restrito do acesso a direitos e à proteção social. Estava aberta a saída interpretativa para o desafio de entender essa particularidade enigmática, a saber, a de mercados de trabalho que, sendo capitalistas, não generalizavam a norma capitalista de emprego ${ }^{6}$. 
A desconexão entre vida social crescentemente monetizada (sustentada num contexto de crescimento econômico e incorporação social persistentes) e restrita regulação institucional do trabalho (e a fortiori do seu mercado) está na raiz do valor simbólico conferido à relação de emprego "típica" no Brasil. Com efeito, a segmentação característica do modelo de cidadania regulada, conquanto de base ocupacional, não se assentava em distinções inerentes à gramática do processo produtivo, mas em diferenças no modo de legitimação política, no tipo de cidadania, que estabeleceu o espectro dos direitos associados ao trabalho, fixou uma cesta de benefícios e $_{\mathbf{1}}$ os associou a um grupo restrito de elegíveis. Consagrava-se, assim, e nesse mesmo movimento de construção/inclusão excludente, o valor simbólico não apenas dos benefícios outorgados, mas (arrisco sugerir)

(i) do mecanismo para a eles aceder-se, vale dizer, o trabalho formalmente registrado;

(ii) de um símbolo, que seria o passaporte para tal acesso: a carteira de trabalho;

(iii)e de um grupo de referência, social e espacialmente circunscrito, qual seja, o dos trabalhadores da indústria e dos serviços, localizados nos centros urbanos.

Desconexão e segmentação não estavam livres de consequências subjetivas, que foram equacionadas sob diferentes formas pela literatura de então. Numa primeira, em que se alinham os trabalhos pioneiros de Juarez Brandão Lopes e Leôncio Martins Rodrigues, sublinha-se a dificuldade para se generalizar, entre esses trabalhadores, uma visão de mundo, uma autoimagem e uma racionalidade centradas no trabalho assalariado. Isso porque, para uma parcela significativa dentre eles, as diferenciações sociais que lhes serviriam como eixos de referência não se assentavam numa norma de assalariamento. Por isso mesmo, a construção política das diferenças não encontraria os seus referentes nas relações de trabalho ou numa norma de emprego assalariado.

Para outros, e Machado da Silva está entre esses, o assalariamento era uma espécie de dispositivo espectral, simultaneamente matriz de referência e alvo de crítica. Nesse sentido, o elogio do trabalho autônomo, "por conta própria" (e "sem patrão"), longe de ser uma persistência do passado, um componente da dimensão tradicional da subjetividade, a orientar a conduta desses novos trabalhadores urbanos, seria, antes, 
uma forma de resistir à condição assalariada e, nesse momento em especial, aos baixos salários pagos no mercado formal ${ }^{7}$.

Esse foi um fértil veio de análise. Importantes debates da sociologia brasileira do trabalho aí se estabeleceram. Foi assim, por exemplo, com a discussão acerca da possibilidade de que um movimento operário de base urbano-manufatureira galvanizasse a luta política, construindo sua hegemonia ideológica por sobre essas profundas heterogeneidades de condições de trabalho e de modos de vida - tema-chave na virada dos anos 1970 para os anos 1980 (ver a respeito, por exemplo, Tavares de Almeida, 1978; Humphrey, 1982; Le Ven, 1983; Leite, 1985; Abramo, 1986; Antunes, 1986; Agier, Castro, Guimarães, 1995; Lima, 1996).

Do ponto de vista da discussão que aqui nos move, esse debate é revelador. Senão, vejamos: as heterogeneidades sociais que chamavam a atenção eram aquelas que segmentavam os trabalhadores entre os ocupados em formas tipicamente capitalistas e aqueles que não logravam inserir-se nesse circuito (ou que nele se incluíam de maneira transitória e fora do coração propulsor da indústria e dos serviços modernos) ${ }^{8}$. Nesse sentido, era na política, e pela via da ação de classe, que se ultrapassaria o hiato estabelecido na estruturação do mercado de trabalho e traduzido na experiência cotidiana dos trabalhadores.

Nos anos 1990, a discussão se reatualiza, agora sob nova roupagem e premida pela urgência de interpretar a reestruturação das firmas e a diversidade das formas de gestão de efetivos por elas adotadas. Disso davam testemunho as variadas maneiras de nomear e hierarquizar os indivíduos, segundo os seus diversos estatutos no "mundo da firma". Assim, os sistemas classificatórios (produzidos nas distintas culturas de empresa e que regiam as relações sociais nesses microcosmos) antepunham os "permanentes" aos "temporários"; outras vezes os "mensalistas" aos "horistas"; e não raro os "regulares" aos "subcontratados".

Salta aos olhos que aí havia algo de novo: não era a natureza do trabalho concreto, a sua ocupação ou a atividade profissional (como se queira) o que os diferenciava; nem tão somente o posto de trabalho; era o modo de se estabelecer a relação de emprego o que passara a se constituir no marcador da diferença socialmente significativa.

A novidade, que a literatura sociológica dos anos 1990-2000 logo soube capturar, vinha da presença de uma nova forma contratual, a dos assim 
chamados "terceirizados". Tal forma impunha a necessidade de teorizar tanto a especificidade desse modo de gestão das diferenças intraempresa, como as suas consequências para a representação de interesses, até ali monopolizada pelo sindicato "da categoria", cujos limites, antes indisputados, passavam a exprimir desconcertante fluidez (ver, a propósito, os trabalhos de Martins e Ramalho, 1994; Abreu et alii, 1998; Druck, 1999).

Os anos 2000 ampliaram o espectro do debate sobre os elos entre heterogeneidade, formas de sociabilidade e ação coletiva, já agora num contexto de contração das oportunidades de emprego nos mercados ditos "externos" de trabalho, e de diferenciação de estatutos nos mercados "internos", no compasso da reestruturação micro-organizacional que se aprofundava. Nessa longa conjuntura de refluxo, a retração do assalariamento formal estancou o movimento que, desde os fins dos anos 1940, incluíra progressivamente novos contingentes de trabalhadores, migrantes em sua maioria, sob o manto da regulação capitalista. Ao fazê-lo, colocou no centro do debate, e integrou, mudança nos locais de trabalho e no mercado de trabalho, sob o acicate do crescente desemprego e da diluição (até mesmo) das trajetórias antes bem-sucedidas dos, agora, "deserdados da indústria" e, por que não dizer "deserdados do trabalho formal" (Cardoso, 2000 e 2003; Guimarães, 2004; Ramalho e Santana, 2006; Ramalho, 2010; Rodrigues et alii, 2009).

Enquanto a agenda dos economistas os polarizava entre os que viam, neste, um caminho sem volta e aqueles que atribuíam à política pública a virtualidade de poder revertê-lo9 ${ }^{9}$ a agenda dos sociólogos abria espaço a mais uma novidade, de importantes consequências para talhar esse contexto. Na esteira das políticas voltadas a sustentar o chamado "empreendedorismo", ampliava-se o marco regulatório das relações de trabalho, difundia-se o trabalho associado em cooperativas, estendendo, em outra direção, o arco de alternativas que desafiavam o peso estrutural e o valor simbólico do emprego formal. Assim, na mesma medida em que o trabalho associado se configurava como uma saída à conjuntura de escassez de empregos ditos "regulares", abria-se outra senda pela qual se aprofundavam os debates sobre as representações acerca do trabalho, da autonomia e dos direitos (Lima, 2009 e 2010; Leite, 2009).

Qual a novidade da segunda metade dos anos 2000, quando o movimento de incorporação produtiva pela via da expansão do emprego 
formalmente registrado parece ter sido restabelecido? Estaremos, pura e simplesmente, frente à retomada da antiga tendência, antes (e apenas circunstancialmente) estancada? O velho e bom "emprego fichado" volta, enfim, a crescer, para alegria de todos e para a efetivação do antigo modo de regulação institucional do trabalho? Diria que não e a isso dedicarei as duas partes que se seguem. Elas me permitirão reunir os elementos para arguir, na conclusão, em favor de repensarmos o tema da persistência do valor simbólico do vínculo formal assalariado nas atuais condições de estruturação do mercado e de regulação da relação de trabalho.

\section{Mais Empregos sob Novos Padrões de Gestão da Relação de Trabalho?}

Observando a performance do mercado brasileiro de trabalho nos dias que correm, um significativo crescimento do emprego formalmente registrado fica visível nos dados da RAIS (Relação Anual de Informações Sociais), nosso melhor termômetro sobre o que se passa no mercado formal de trabalho ${ }^{10}$. Observando, no Gráfico 1, a série histórica que recobre os anos posteriores ao Plano Real (1994-2010), vê-se uma inflexão que tem lugar a partir de 2002. O mercado formal se reanima, e passa a crescer a taxas mais elevadas que fazem dobrar o numero de traba-

Gráfico 1

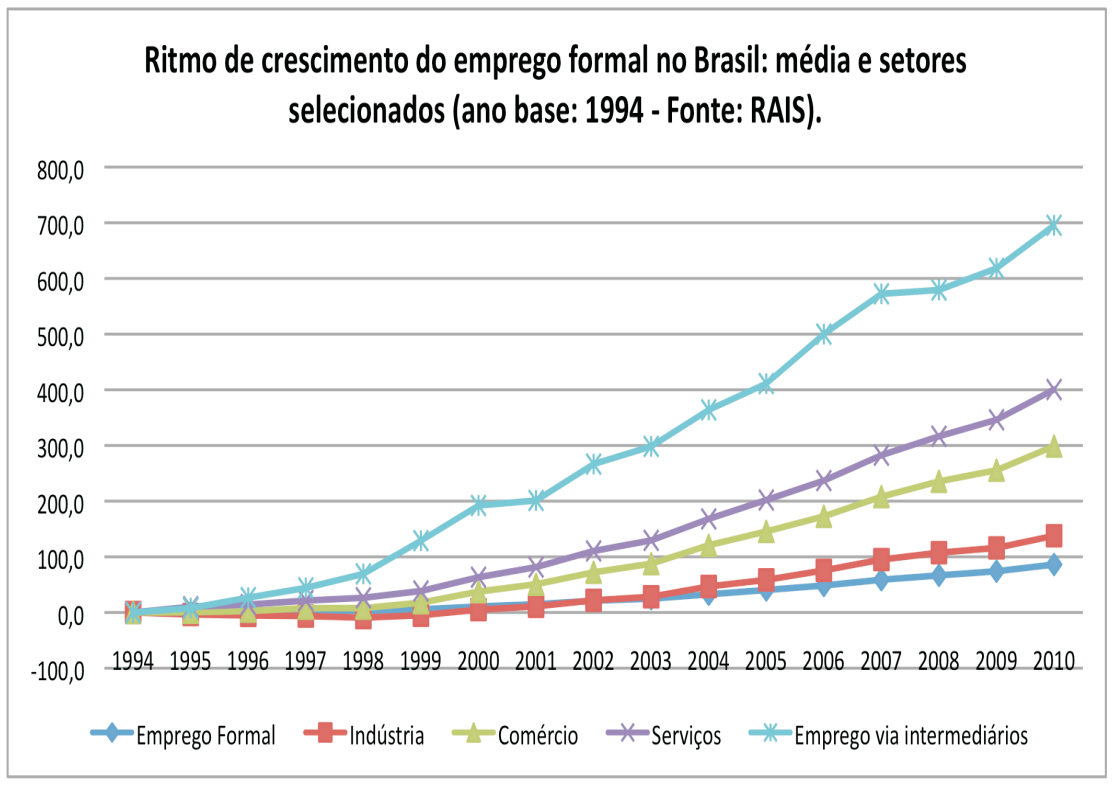


lhadores contratados no comércio (139\%) e nos serviços (105\%); até mesmo na indústria, que experimentara taxas negativas entre 1995 e 2001, o volume do emprego registrado cresceu $46 \%$ numa comparação ponto a ponto.

O mais interessante achado que se apresenta no Gráfico 1, entretanto, diz respeito ao ritmo muito mais elevado com que aumenta a parcela do emprego formal gerada pelas empresas de seleção, agenciamento e locação de mão de obra. Ele cresce quase $300 \%$ no mesmo período (mais exatamente 272\%). Vale dizer, quando a economia se reanima e as oportunidades de trabalho se ampliam, o emprego formal gerado através de intermediários cresce muito mais celeremente que o incremento no assalariamento direto, não importando o setor de atividade com o qual se compare tal crescimento.

Estará tal movimento circunscrito a certos espaços do território nacional? Com efeito, seria plausível pensar que, quando firmas enxutas voltam a recrutar num mercado de trabalho prenhe de desempregados, o custo desse recrutamento, dado o afluxo desmesurado de candidatos, pode justificar o ônus de investir na presença de um terceiro agente, o intermediador. Ademais, se supusermos que o custo de recrutar é maior a escalas crescentes de operação do mercado, o recurso a intermediários seria tanto mais plausível, portanto, quanto maior fosse a oferta de trabalhadores e a concentração desses. Um argumento dessa natureza nos levaria a concluir que o notável crescimento do emprego produzido através de intermediários tenderia a ser um fenômeno exclusivo de mercados de larga escala, como os mercados metropolitanos.

O Gráfico 2 revela que isso só em parte é verdadeiro. Nele se compara o movimento no volume dos contratos de trabalho via intermediários em duas diferentes escalas espaciais: para o Brasil como um conjunto e para as nossas regiões metropolitanas.

O que vemos? Em primeiro lugar, que a inflexão das duas curvas exprime um padrão muito similar e que, ademais, a proximidade existente entre ambas indica, como hipotetizado acima, o peso dos grandes mercados na ampliação recente desse tipo de serviço e de relação de emprego. No caso brasileiro, é evidente que a escala importa. Só o Estado de São Paulo concentra metade de todo o emprego intermediado que se criou no país; e sua região metropolitana produziu a parcela majoritária dessas vagas (Guimarães, 2009:139). 
Gráfico 2

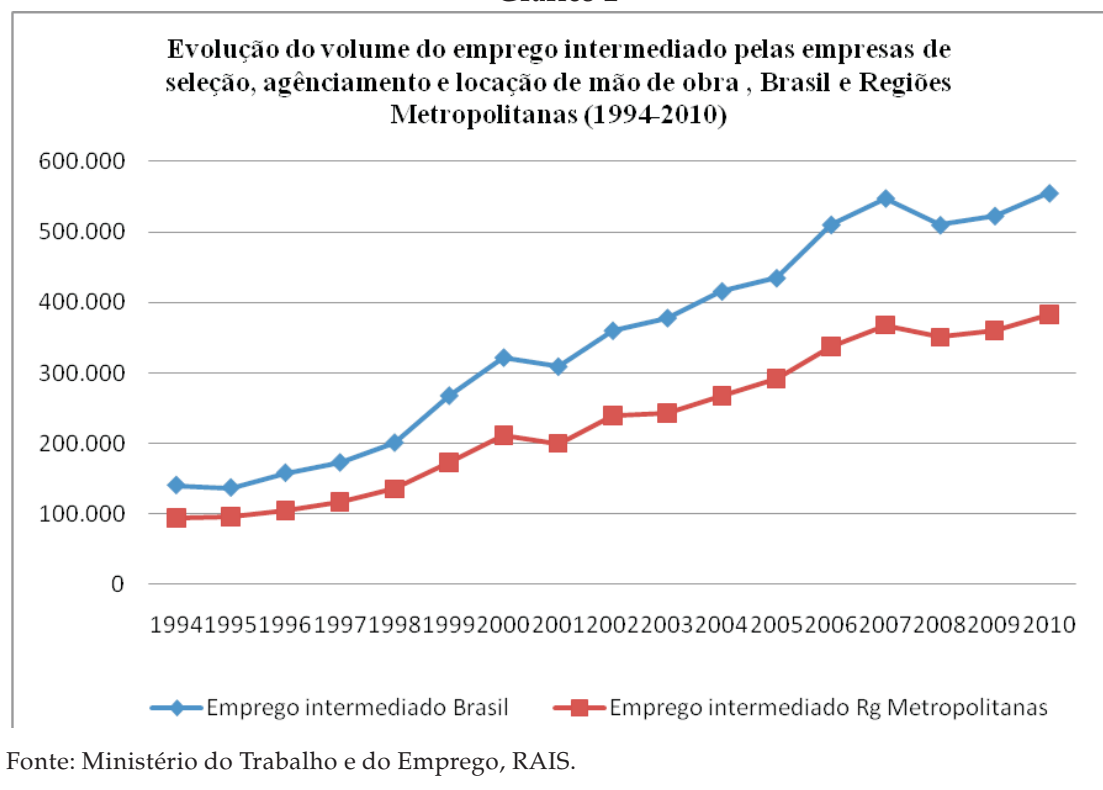

Apesar disso, uma segunda observação se destaca: há um hiato entre as duas curvas, que parece se ampliar justamente na conjuntura em que mais celeremente cresce o emprego formal; vale dizer, estamos diante de um processo que, conquanto concentrado, repercute para além dos limites dos grandes mercados metropolitanos.

Finalmente, o Gráfico 2 revela como o emprego intermediado é sensível ao ciclo. O leve refluxo na atividade econômica no Brasil, associado à crise internacional que se deflagrou em 2008, teve efeito imediato sobre o volume de ocupação nesse segmento. Mas, foi também imediato o efeito da recuperação da economia, no ano seguinte, que rapidamente fez crescer as oportunidades criadas pelos intermediadores de trabalho, a revelar que a inflexão fora meramente conjuntural e que a tendência à expansão do setor veio para ficar.

Todavia, há que tomar uma precaução. Diante dos impactantes números relativos que expressam ritmos de crescimento, como os do Gráfico 1 , não devemos perder de vista que esse é um segmento minoritário no mercado formal de trabalho, o que fica patente no Gráfico 2. No Brasil, e ainda de acordo com a RAIS, a magnitude do emprego formal criado através de intermediários equivale apenas a cerca de $2 \%$ do emprego com carteira assinada e, nesse sentido, nem de longe rivaliza com o em- 
Gráfico 3

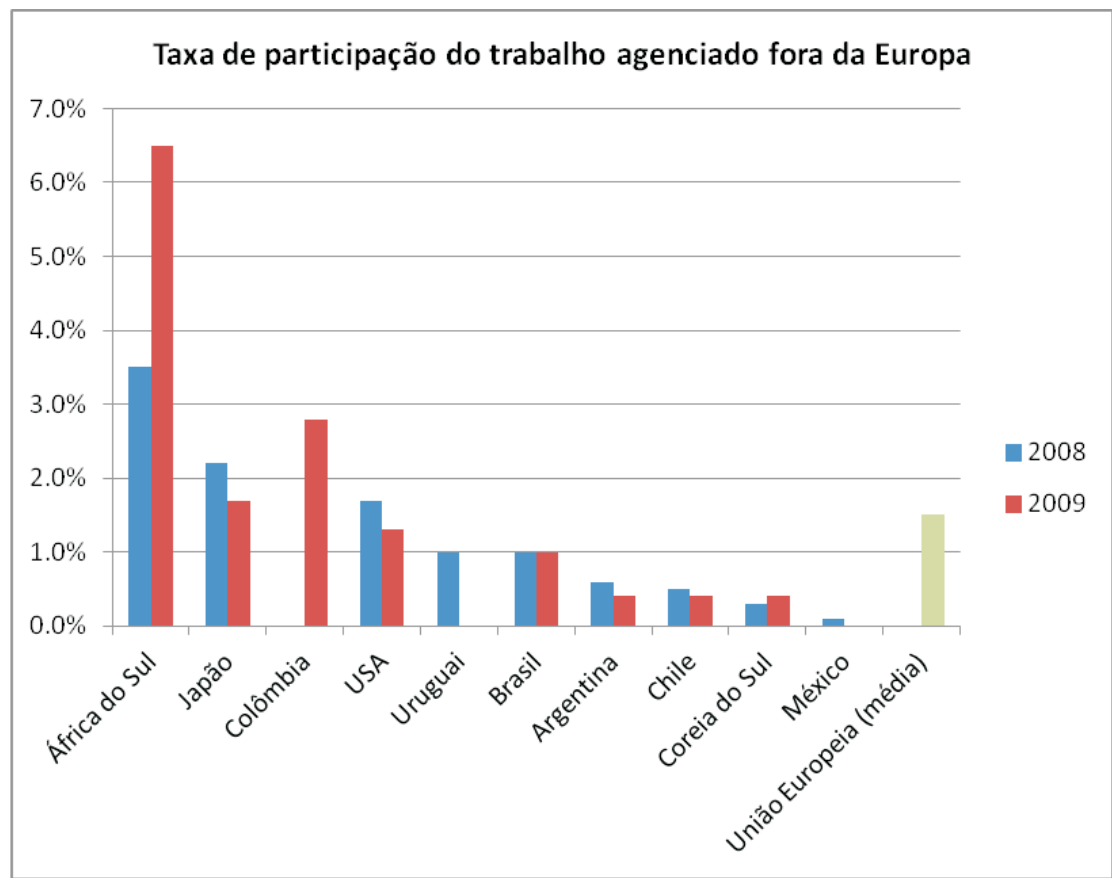

Fonte: CIEET - International Confederation of Private Employment Agencies. Economic Report - The Agency Industry around the World, 2010 (ano-base 2009) e 2011 (ano-base 2010).

prego diretamente contratado. Sendo assim, por que lhe dar tamanha atenção?

Em primeiro lugar, porque o percentual encontrado para o nosso país não dista muito do que se verifica em outros quadrantes, onde o setor já se apresenta consolidado. Estatísticas produzidas pela International Confederation of Private Employment Agencies (CIEET), em seus dois últimos relatórios referentes a dados de 2008 e 2009 (respectivamente CIEET, 2010 e 2011), e resumidas no Gráfico 3, permitem situar o Brasil no quadro internacional. Elas nos dão a medida do peso do trabalho intermediado em distintos países, comparando-os com a média europeia ${ }^{11}$. Considerando-se o indicador da CIEET relativo ao volume absoluto do emprego provido por intermediadores, o Brasil, tanto em 2008 quanto em 2009, só era ultrapassado pelos Estados Unidos, Japão, Reino Unido e África do Sul (Gráfico 3).

Dados de outra fonte brasileira nos permitem confrontar a informação fornecida pelas empresas (e obtida da RAIS) com a informação forneci- 
Gráfico 4

Evolução da \% de Subcontratados entre os assalariados

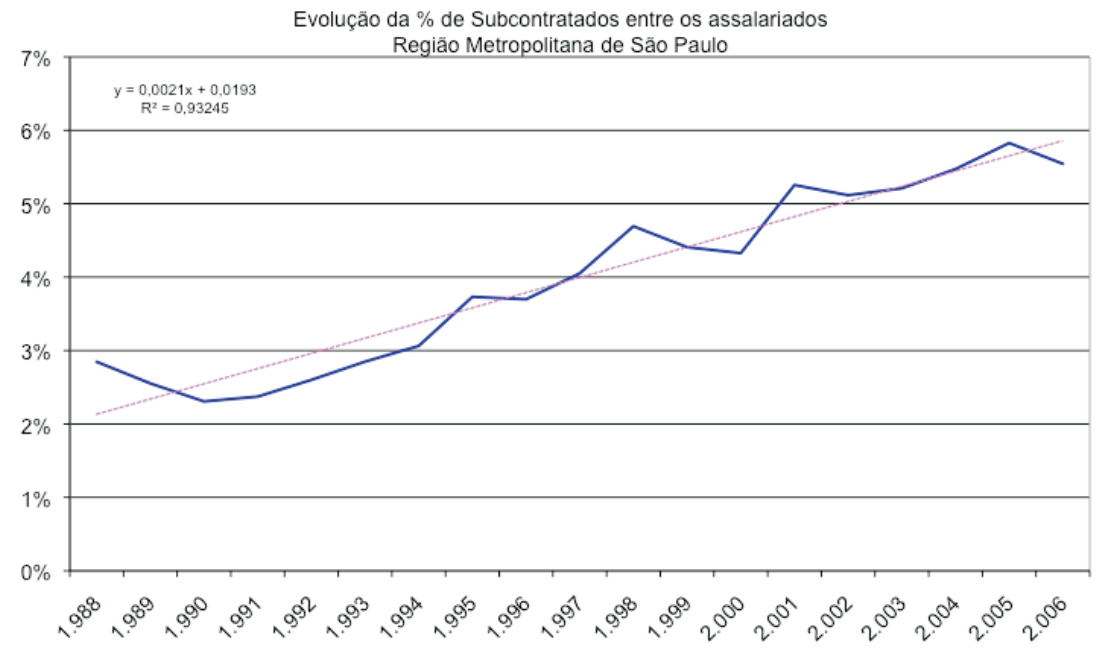

Fonte: Fundação SEADE, Pesquisa de Emprego e Desemprego.

da pelos trabalhadores. Isso é possível se usarmos a Pesquisa de Emprego e Desemprego, inquérito domiciliar e mensal, por amostra representativa, realizado para algumas das metrópoles brasileiras e que nos provê com uma série histórica igualmente robusta.

Focalizarei a Região Metropolitana de São Paulo, o mais importante viveiro de trabalho intermediado entre todas as metrópoles brasileiras, localizada no Estado campeão no uso de trabalho intermediado. Observando o longo período compreendido entre 1988 e 2006, vê-se que esse tipo de vínculo formal é sensivelmente maior ali que na média nacional, antes apresentada com base na RAIS; ademais, no momento de recuperação dos postos formais, o peso do trabalho contratado através de terceiros quase que dobrou, alcançando perto de $6 \%$ dos assalariados na metrópole paulista (ver Gráfico 4$)^{12}$.

À luz dos dados até aqui apresentados, vemos que, quando o crescimento econômico volta a ampliar oportunidades ocupacionais, não se pode dizer que estejamos, pura e simplesmente, frente à retomada da mesma tendência, conjunturalmente estancada, que marcara a dinâmica do nosso mercado de trabalho até o final dos anos 1970. A novidade dessa segunda metade dos anos 2000 está no fato de que vem crescendo (de modo ainda mais célere, nacional, conquanto concentrado 
nos nossos grandes mercados de trabalho) um tipo de relação de emprego que, se existia anteriormente, era muitíssimo mais circunscrita.

Do ponto de vista formal o trabalho obtido através das empresas de seleção, agenciamento e locação de mão de obra altera a relação contratual e nela introduz um terceiro, que se interpõe entre os clássicos agentes do mercado, o ofertante e o demandante de trabalho. Do ponto de vista da sua regulação institucional, ele vivifica as possibilidades de regulamentação do trabalho temporário, de curta duração, ao mesmo tempo em que traz para o âmbito do que pode ser formalmente contratado esse tipo de atividade (Bicev, 2010).

Em outras oportunidades procurei seguir avançando na resposta à indagação sobre a qualidade e a sua seletividade desse tipo de vinculo (Guimarães, 2009a e 2009b). Assim, observei a durabilidade dos contratos estabelecidos por esses trabalhadores e a especificidade das suas trajetórias ocupacionais. A esse respeito, poder-se-ia dizer que a retomada do crescimento do emprego formal estaria se fazendo por meio de uma crescente flexibilização de tipo rudimentar das relações de trabalho?

Explorando os dados longitudinais da RAIS, disponibilizados num corte especial do banco da Rais-Migra ${ }^{13}$, pode-se acreditar que também aqui a resposta está longe de ser simples, requerendo cuidado e refinamento analíticos. Nos trabalhos antes citados, mas também na investigação conduzida por Jonas Bicev, foi possível observar as trajetórias dos trabalhadores ocupados através de intermediários, identificando os seus percursos no mercado formal de trabalho.

Para tal, utilizei uma amostra de 143.000 indivíduos, extraídos da Rais-Migra, que formavam uma coorte de trabalhadores empregados, em 1996, nas empresas de seleção, agenciamento e locação de mão de obra da Região Metropolitana de São Paulo, de modo a identificar o seu percurso ocupacional até 2002, último ano para o qual dispunha de informações (Guimarães, 2009a). Acompanhei, assim, sete anos da vida profissional desses indivíduos, de modo a verificar quão estável era a sua permanência no segmento e se, uma vez movendo-se, em que direção o faziam. Embora não os tenha observado no momento de maior ampliação das oportunidades de emprego, os resultados são fortemente sugestivos e nos impedem de insistir em hipóteses aligeiradas, que tudo incluem sob a ampla, e com frequência vaga, noção de "precarização". 
Verifiquei que, se o segmento de intermediação não se revela um abrigo duradouro para os trabalhadores que por ele passam (apenas $1 \mathrm{em}$ cada 10 permanece por longo tempo ali empregado), ele propicia que uma parcela importante dos que por ali circulam possa se reempregar em outros setores de atividade, como a indústria e os serviços prestados a empresas. Com efeito, um quarto da coorte de trabalhadores que haviam estado empregados por empresas de locação, em 1996, estabelecem vínculos posteriores, ao longo do período, nesses setores ${ }^{14}$. Esse achado converge com evidências obtidas em outras realidades, como a dos Estados Unidos (Autor e Houseman, 2006; Autor, 2008), e foi documentado igualmente por Bicev (2010).

Uma análise de trajetórias construída em sentido contrário, ou seja, retrospectiva em vez de prospectiva, produziu achados bastante complementares aos anteriores. A pergunta passava a ser "de onde provêm os trabalhadores que logram obter emprego numa empresa de intermediação?", vale dizer, qual o papel dos intermediários no que concerne à inserção dos indivíduos no mercado de trabalho? Para tal, e ainda usando o mesmo banco de dados, tomei a coorte das cerca de 288.000 pessoas que estavam ocupadas nas empresas de intermediação em 2002 e, com base nas informações propiciadas pela Rais-Migra com respeito a esses trabalhadores, montei um painel que recuperava todas as suas experiências ocupacionais nos sete anos anteriores à sua chegada no segmento, ou seja, entre 1996 e 2002 (Guimarães, 2009a).

Chamou a atenção o peso daqueles que haviam estado fora do mercado formal de trabalho e que para ele foram atraídos pelas empresas de seleção, agenciamento e locação de trabalhadores; eles formavam nada menos que a metade dos casos. E quem eram esses trabalhadores atraídos ao vínculo formal pelos intermediários? As mulheres eram ligeiramente mais prováveis de ser encontradas nesse tipo de trajetória. Mas foi entre os adolescentes e jovens, com escolaridade de nível médio, que parecia estar o celeiro para tal recrutamento; ou seja, eles encontravam nas empresas de intermediação a porta de entrada para o vínculo formal de trabalho (Guimarães, 2009a).

Articulando os achados anteriores propiciados pela Rais-Migra com respeito às trajetórias de chegada e de saída no setor, algumas observações sugestivas parecem cabíveis com respeito a essa relação de emprego de crescimento recente e vigoroso. 
Em primeiro lugar, os que se ocupam por meio das empresas de seleção, agenciamento e locação, mesmo se com elas rompem seus vínculos de trabalho (e 9 em cada 10 o fazem em 7 anos), tendem a permanecer, em sua maioria (isto é, 6 em cada 10) e de modo duradouro (isto é, persistentemente no lapso de 7 anos), no mundo dos empregos registrados (Guimarães, 2009a). Ou seja, é como se um movimento de permanência no mercado formal estivesse se fazendo por meio de um processo recorrente de restabelecimento de vínculos, para o qual a passagem por empregos intermediados parece ter funcionado como uma correia de transmissão relevante para a inserção.

Todavia - e em segundo lugar -, essa correia de transmissão é de eficácia relativa, já que uma parcela importante volta a estar duradouramente expulsa do mercado formal; algo assim como 4 em cada 10, se usarmos os dados das trajetórias prospectivas, média similar à que encontrei em estudo anterior para o Brasil (Guimarães, 2004). Nada a estranhar em se tratando de uma realidade na qual o desemprego, mesmo com a retomada do crescimento, não perdeu o seu caráter recorrente, especialmente entre os mais pobres, e em que a institucionalização das formas de proteção ainda é recente, exigente por seus critérios de elegibilidade e pouco inclusiva.

Finalmente, e em terceiro lugar, trata-se de um segmento complexo que, na forma como foi institucionalizado, estabelece novas maneiras de acesso, inclusão e mobilidade no mercado formal de trabalho no Brasil, maneiras essas que ampliam a heterogeneidade entre os que estão contratados com registro, e espelham as mudanças institucionais em curso nas empresas e no próprio mercado. Difícil, assim, equacionar o tema apondo, nesses agentes, o rótulo de protagonistas de uma flexibilidade de tipo rudimentar. Se mais não fosse, porque flexibilidade nós a vivemos desde sempre, sob o acicate seja de um mercado de trabalho estruturalmente heterogêneo, no qual uma "norma salarial" (produto de conquistas sociais geradas em estados de bem-estar) jamais se universalizou; seja sob o acicate da regulação institucional que atingiu aquela pequena parcela dos empregados formais e que, introduzida logo nos primeiros momentos do regime militar sob a forma da legislação do Fundo de Garantia do Tempo de Serviço, em 1965, retirou-lhes o direito à chamada "estabilidade".

Assim, parecemos estar numa rota de flexibilização do que já era flexível, no curso da qual se fragilizam vínculos nos setores econômicos em 
O Que Muda Quando se Expande o Assalariamento...

reestruturação, ao tempo em que se (re)constituem vínculos formais de trabalho de diversa natureza, com peso crescente para aqueles que se fazem através das empresas de seleção, agenciamento e locação de pessoal. Esse parece ser o novo desafio cuja natureza e consequências, do ponto de vista simbólico e das formas de sociabilidade, nós, os sociólogos, estamos desafiados a bem interpretar.

\section{RECONFIGURANDO-SE AS RELAÇÕES DE EMPREGO, RECONFIGURAM-SE AS RELAÇÕES ENTRE EMPRESAS?}

Para finalizar o percurso analítico, gostaria de deixar plantado um último argumento. Para tal, começo por situá-lo com respeito ao fio da reflexão até aqui desenvolvida.

Na segunda metade dos anos 2000 observamos, no Brasil, uma notável recuperação do emprego formal, da qual tratamos na primeira seção deste texto. Nesse crescimento, entretanto, prefigura-se a crescente importância de uma forma particular de relação contratual entre empregado e empregador, o trabalho intermediado. Ele estaria aumentando, entre nós, de maneira sistemática e a taxas notáveis. Conquanto especialmente significativo nos grandes mercados de trabalho, com destaque para a Região Metropolitana de São Paulo, esse crescimento tem revelado um ritmo médio nacional a cada ano mais acelerado, indicando uma tendência a expandir essa relação de emprego por setores e regiões. E se é fortemente imune a retrações na atividade, rapidamente responde (e se recupera) quando esta retoma a sua aceleração.

Do ponto de vista do seu impacto sobre a força de trabalho intermediada, vimos, na segunda seção do texto, que dificilmente ele poderia ser reduzido a estereótipos simplificadores que, conquanto politicamente bem intencionados, são analiticamente paralisantes. Com efeito, na análise antes apresentada sobre as trajetórias dos ocupados por meio de intermediários, documentou-se, tomando a Região Metropolitana de São Paulo como exemplo, que a ocupação assim obtida tem se constituído num passaporte de entrada no mercado de trabalho para parcela não desprezível de indivíduos, notadamente os mais jovens. Mais ainda, que muitos deles, depois de algum tempo contratados por intermediários, são absorvidos em setores nos quais são diretamente contratados por seus empregadores. E que, se rotatividade existe entre os trabalhadores empregados por meio de intermediários, ela não é mui- 
to distinta daquela que prevalece para a média dos empregados formalmente contratados no Brasil.

Assim sendo, e para finalizar a apresentação de evidências empíricas analiticamente instigantes, seria oportuno indagar, agora, acerca do efeito do significativo crescimento dessa modalidade de emprego não apenas para as relações entre empregado e empregador, mas para os nexos entre os próprios empregadores. Isso porque, e essa é a hipótese que quero aventar, na medida em que o trabalho intermediado deixa os nichos antes característicos da subcontratação, ele altera aqueles que parecem ter sido seus traços anteriores: de ser episódico do ponto de vista do ciclo da produção de bem ou serviço; de ser compensatório do ponto de vista de ocupações nas quais se concentrava; e de ser setorialmente localizado.

Sugiro e procurarei argumentar que se alteram as próprias relações entre as firmas - provedoras e usuárias do serviço de intermediação do trabalho - quando o trabalho intermediado amplia suas formas, ancorado numa nova regulação institucional, tornando-se um negócio atraente, operante de maneira permanente, em escala plurissetorial e multirregional, abarcando, inclusive, o trabalho de gestão dos seus recursos humanos, crescentemente externalizado pelas firmas. Ou seja, seu lugar é central nessa nova quadra da ordem econômica.

Analisando-o de maneira mais detida - e esse será o ponto-chave do argumento nesta seção - vemos que tal fenômeno é um indício não apenas de que um outro modo de gestão do recrutamento e dos contratos de trabalho está se ampliando, mas de que um pujante segmento de negócios - o da intermediação de trabalho - consolida-se na economia brasileira. Com isso, passam a ter lugar formas complexas de articulação entre firmas provedoras e usuárias de trabalho intermediado, numa rede mais organicamente tecida.

Tratarei o tema a partir da resposta a duas indagações: a quem servem esses intermediadores que atuam no mercado de trabalho? Como servem, vale dizer que tipo de serviço provêm e sob que tipo de relação de provimento?

Para tanto, novamente lançarei mão de dados para o Estado de São Paulo, únicos disponíveis ao nível de detalhe de que necessitarei na demonstração. Tais informações são provenientes PAEP - Pesquisa da Atividade Econômica Paulista 2002, e foram recolhidos em survey realizado junto à amostra representativa das empresas em atividade no 


\section{Gráfico 5}

Percentual das Receitas por Tipo de Cliente

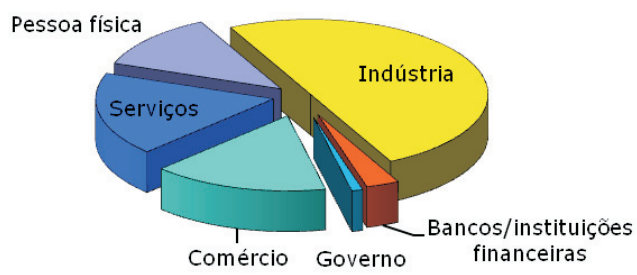

$\begin{array}{ll}\square \text { Pessoa física } & \text { andústria } \\ \square \text { Bancos/instituições financeiras } & \square \text { Governo } \\ \text { aComércio } & \square \text { Serviços }\end{array}$

Fonte: Fundação Seade, PAEP - Pesquisa da Atividade Econômica Paulista, 2001.

ano 2001. Para a análise subsequente selecionei, da amostra original para um olhar mais detido, as empresas provedoras de serviços de intermediação no campo do provimento e gestão de recursos humanos ${ }^{15}$.

O Gráfico 5 apresenta a decomposição das receitas auferidas por essas empresas segundo o tipo de cliente.

Vê-se, à luz desses dados, que não é mais o governo, como nos primórdios da história desse segmento de negócios, o principal cliente da intermediação de trabalho ${ }^{16}$. São os setores diretamente produtivos, notadamente as empresas industriais, as quais respondem por metade da receita auferida pelas empresas intermediadoras. Ou seja, o trabalho intermediado cresce no coração da atividade econômica, reconfigurando o cerne da relação social de trabalho que até aqui lhe fora característica.

Por outro lado, os vínculos estabelecidos com as empresas usuárias dos seus serviços estão longe de se restringirem à simples locação de trabalho (ou seja, são mais que meras provedoras de trabalhadores), e tampouco poderiam ser classificados como frágeis em sua duração ou precários em sua formalização. Para melhor evidenciar a estreita e complexa conexão que firmas provedoras e usuárias guardam entre si, os gráficos seguintes comparam o padrão de relação interfirma nesse segmento com aquele que caracteriza outros segmentos da atividade econômica que provêm insumos estratégicos para as empresas que os 
Gráfico 6

Natureza da Relação Contratual

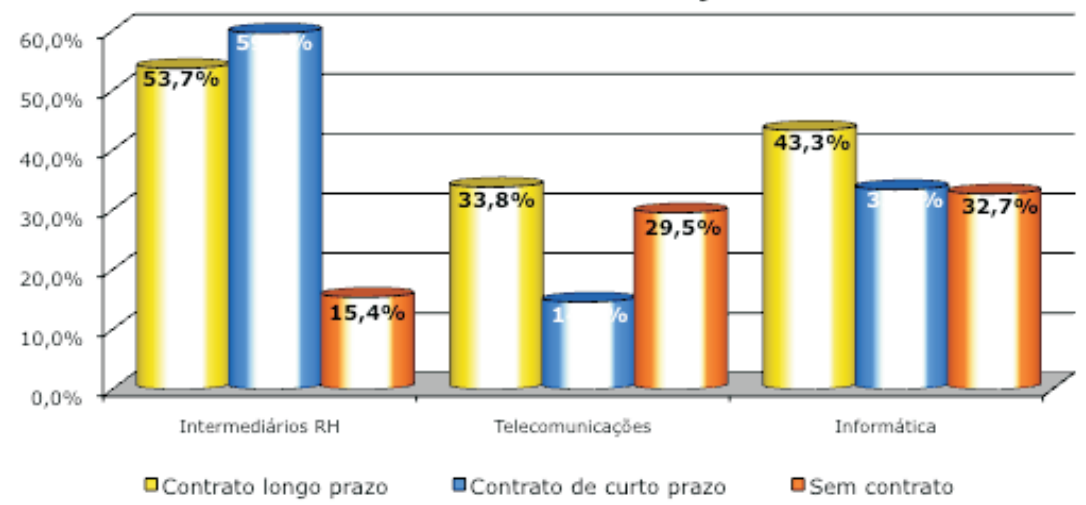

Fonte: Fundação Seade, PAEP - Pesquisa da Atividade Econômica Paulista, 2001.

Obs: Resposta múltipla. Contrato de longo prazo: > que 1 ano; Curto prazo: < que 1 ano.

contratam, como são as empresas provedoras de serviços de telecomunicação e de informática.

Minha indagação poderia ser assim formulada: terão as empresas provedoras de serviços relativos à mão de obra um padrão distinto de relação com as empresas (usuárias) que as contratam? Ou seja, elas se diferenciariam do padrão que se estabelece em outros segmentos, comumente classificados como "modernos e inovadores" (como telecomunicações e informática), e que provêm outros insumos igualmente importantes?

Como se pode observar no Gráfico 6, na maioria expressiva das transações que realizam, as fornecedoras de serviços de provimento e gestão de recursos humanos têm o seu relacionamento com as empresas usuárias dos seus serviços regido por contratos; menos que 20\% de transações foram referidas como realizadas sem o respaldo de um instrumento formal que fixasse os termos da relação entre as duas firmas. Relações informais, curiosamente, são mais frequentes entre empresas fornecedoras de serviços de telecomunicação e informática e as firmas usuárias desses serviços, que no campo da intermediação de trabalho.

Mais interessante ainda, relações duradouras não são excepcionais; mais que $50 \%$ das intermediadoras indicaram transações firmadas para prestação de serviços a clientes por período maior que um ano. E, novamente, a estabilidade da relação com a firma contratante é maior entre elas que entre as empresas atuantes em ramos típicos do segmen- 
O Que Muda Quando se Expande o Assalariamento...

\section{Gráfico 7}

Importância da relação de serviço: fornecedor exclusivo

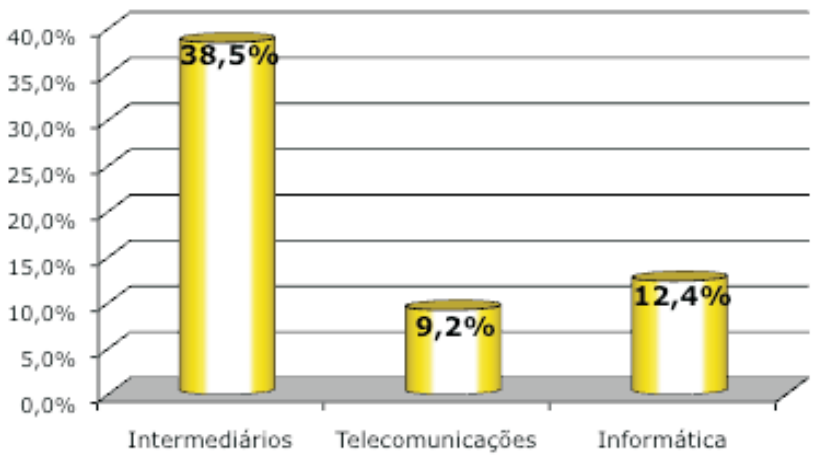

DExclusividade no fornecimento

Fonte: Fundação Seade, PAEP - Pesquisa da Atividade Econômica Paulista, 2001.

to intensivo em conhecimento da economia, como são as empresas de informática e telecomunicação.

O Gráfico 7 traz outra evidência que vai na mesma direção: relações de exclusividade no provimento do serviço são muito mais frequentes

\section{Gráfico 8}

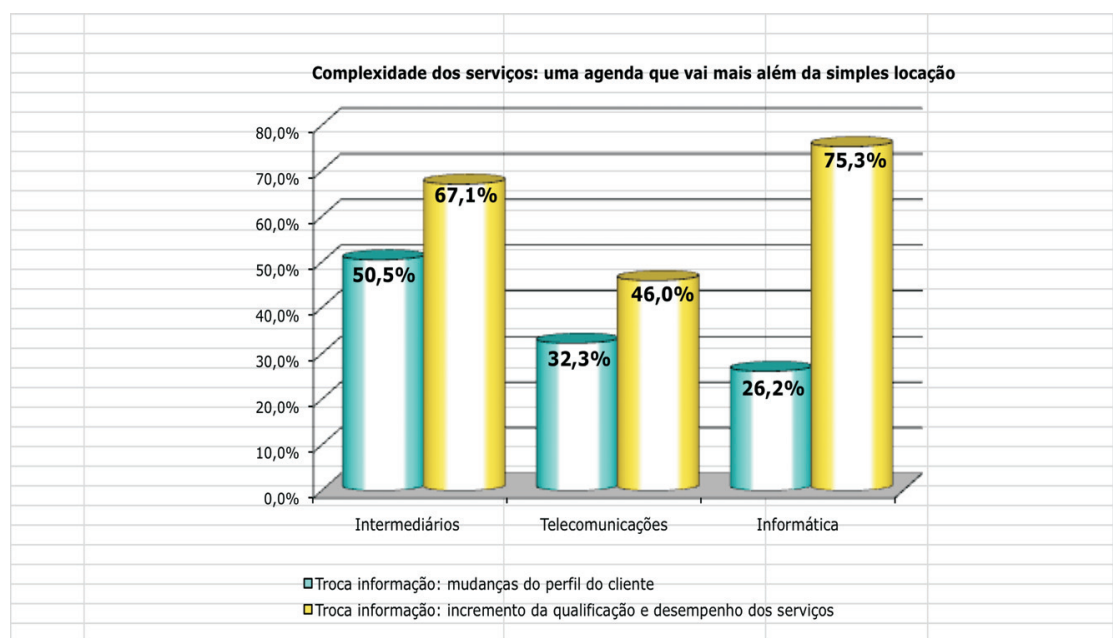

Fonte: Fundação Seade, PAEP - Pesquisa da Atividade Econômica Paulista, 2001. 
quando se trata de intermediação de trabalho; ou seja, nesse segmento parcela significativa dos contratos liga não apenas duradouramente, mas de modo particularmente estreito, contratante e contratado. Aqui a tendência observada no segmento da intermediação dista ainda mais daquela encontrada para telecomunicação e informática, ramo em que cada empresa fornecedora de serviços tem, e em muito maior proporção, competidoras, igualmente integradas à empresa usuária, prontas a abocanhar suas fatias de contrato.

A modalidade de relação entre firmas provedoras e usuárias de trabalho é não só formal, como durável, estreita e, diria para finalizar, multifacetada, ou seja, ela envolve, tal como se pode ver no Gráfico 8 , uma agenda complexa porque vai muito além da mera locação de trabalhadores. Na relação com as usuárias que as contratam, elas avançam em direção à política de recursos humanos, abarcando tanto o perfil desta, quanto a qualificação da usuária para implementar inovações introduzidas com vistas a aumentar a sua competitividade.

\section{CONCLUSÃO}

Em síntese, intermediadores no mercado de trabalho formam um segmento empresarial que cresce desde os anos 1990 com o aprofundamento da reestruturação das firmas, e que intensifica sua presença de maneira notável quando a economia aquece seus motores e amplia a oferta de vagas na segunda metade dos anos 2000.

$\mathrm{Na}$ esteira do seu crescimento são fortes os indícios de que o contrato formal de trabalho, ao abarcar mais indivíduos, altera a modalidade do novo emprego que se provê, notadamente às mulheres e aos mais jovens. Se as novas formas de regulação do emprego, do que o trabalho intermediado é uma modalidade particularmente importante, não são a panaceia que os apologistas da desproteção do trabalho querem fazer crer (do que dão testemunho a persistente fragilidade do vínculo e instabilidade das trajetórias, similar ao que já se observava no mercado), tampouco são descartáveis os seus efeitos, seja como via de acesso ao trabalho registrado, seja como via de ingresso a empregos diretos nas empresas usuárias.

Mais ainda, a presença das firmas de intermediação de trabalho, a menos pelo que se pode observar no mais importante polo de atividade produtiva do pais, o Estado de São Paulo, denota a constituição de um padrão de relação entre empresas que vai muito além da mero agencia- 
mento de empregados, que um dado intermediador recruta episodicamente para um contratante; ou da simples locadora de força de trabalho, que também episodicamente provê mão de obra em momentos-chave da atividade da empresa usuária. Arriscaria dizer que essas foram formas de relação num passado recente (o dos anos 1980, por exemplo) e que tenderam a ser deixadas para trás.

O cenário até aqui descrito indica estarmos frente a um aglomerado produtivo fortemente integrado, no qual planejamento, recrutamento e alocação de trabalho são atividades que, conquanto crescentemente externalizadas, são desenvolvidas em estreita (e muitas vezes exclusiva) articulação entre o intermediador e o usuário que o contrata. Não sem razão, ao longo do nosso trabalho de campo, gerentes e proprietários de empresas de seleção, agenciamento e locação de trabalhadores (como são denominadas na classificação oficial para atividades econômicas) resistiam e recusavam a usar para si a denominação de "intermediadores de trabalho"; longe disso, esses profissionais e CEOs viam a si próprios como "parceiros", "consultores", "planejadores" do uso dos recursos humanos para as firmas que os contratavam.

Isso permite finalizar sugerindo que, se novas modalidades de relação de emprego parecem estar reconfigurando o velho "trabalho formal", essa reconfiguração não seria mais que a ponta do iceberg de mudanças que estão ocorrendo na organização da economia, com impactos importantes sobre o mercado de trabalho, que a Sociologia está desafiada a bem interpretar.

Elas recolocam na ordem do dia a inquietação que mobilizou autores como Juarez Brandão Lopes, nos anos 1950-60: seria cabível imaginar que, para esses novos trabalhadores, sua visão de mundo, sua autoimagem e sua racionalidade de conduta passariam a estar, agora, irremediavelmente fundadas no trabalho assalariado?

Mas, elas também restabelecem a importância do tema que desafiou Luiz Antonio Machado da Silva e outros autores, nos anos 1970-80, que se detiveram a pensar sobre as heterogêneas configurações do trabalho e os elos que essas guardariam entre si: seria plausível arguir que a expansão da intermediação, ao reconfigurar "o velho trabalho formal", tensionando seus limites, estaria estabelecendo uma sorte de nova fronteira, que restabeleceria o elo perdido entre aqueles que foram pensados como dois grandes segmentos do mercado brasileiro de trabalho? Nessa fronteira cinzenta reúnem-se, agora, características antes 
dissociadas, porque diferenciadoras do que se entendia como formal e informal; do primeiro, o trabalho intermediado preserva os direitos formais e, quem sabe, atualiza a vigência simbólica; do segundo, retém a flexibilidade e a fugacidade dos vínculos, e quem sabe os salários mais baixos. Quem povoa tal fronteira? Como vimos, indivíduos que ali acorrem em suas estratégias de vida, muitas vezes por razões diferentes conforme sejam jovens, mulheres, procurando maximizar a associação entre seus atributos e trajetórias ${ }^{17}$.

Mas essa é uma fronteira que, como todas, também aparta. Nem todos têm acesso ao trabalho intermediado. Conforme mostrei em outra ocasião (Guimarães, 2009a) os intermediadores formam um dique de contenção em meio à volumosa demanda formada pelos que estão à cata de oportunidades, operando a triagem daqueles que considera como "bons candidatos" ou "bons trabalhadores potenciais a alocar". Em meio a uma crescentemente complexa divisão social do trabalho, e ao cipoal do quadro jurídico formal, ali está o seu nicho empresarial, cuja razão de ser se assenta em dois pilares. Por um lado, na capacidade de efetuar a triagem, a seletividade, estabelecendo uma barreira, exercendo o poder de exclusão, enfim, sobre a parcela majoritária dos que a eles recorrem. Por outro lado, na virtualidade de promover o ajustamento "interno", legal e legitimado entre o que era aspirado como um valor simbólico inelutável - o trabalho duradouro, protegido, passaporte ao mundo de direitos - e o multifacetado espectro de formas do formal ("terceirizados", "temporários", "estagiários", só para usar a gramática atual) que a nova forma de gestão das firmas e dos seus efetivos permite acenar como vias de inclusão, em sintonia, cada vez mais fina, com os movimentos de contração e expansão da atividade das empresas.

Estamos, enfim, desafiados a construir uma outra narrativa analítica acerca das novas formas e condições da mobilização do trabalho, que não comporta respostas simples e que nos desafia à contínua pesquisa empírica e reflexão teórica ${ }^{18}$.

(Recebido para publicação em abril de 2011)

(Reapresentado em setembro de 2011)

(Versão definitiva em novembro de 2011) 


\section{NOTAS}

1. Sei que os estudos acerca da estrutura do emprego e da dinâmica do mercado de trabalho galvanizaram os economistas e polarizaram suas posições, premidas pelo desafio de estabelecer o lugar da política econômica e o papel do estado nessa seara. Conquanto reconheça a relevância dessa abordagem e saiba quão acercada ela está do terreno em que construo o meu próprio argumento, convém aclarar que não é esse o partido analítico adotado nas páginas que se seguem; nelas, o foco estará voltado, antes, a refletir a partir de algumas interpretações seminais produzidas pela Sociologia. Não obstante, e dado o valor do debate protagonizado pelos economistas, remissões ocasionais serão inescapáveis.

2. É sugestivo da crescente importância dessas atividades o fato de que a última reforma no sistema classificatório oficial (que instituiu a CNAE 2.0 desde 2006) tenha promovido maior desagregação (na coleta e divulgação) das alternativas de atividade econômica contempladas por esse ramo de "empresas de seleção, agenciamento e locação de pessoal" (código 74.500).

3. Em ocasião anterior tive a oportunidade de refletir sobre esse tema, conquanto sob enfoque distinto do que aqui se desenvolve (Guimarães, 2009).

4. É curioso observar que, nesse sentido, o enfoque das teorias da marginalidade foi precursor da ideia da "redundância", que reapareceria com vigor entre autores que, nos anos 1990, buscaram interpretar a crise do emprego em contextos de intensa reestruturação nos países capitalistas centrais, dentre eles DiPrete e Nonnemaker (1997) e Elias (1994 e 2004).

5. Não sem razão, para Machado da Silva, o clientelismo teria sido, por muito tempo e/ou para muitos contingentes de trabalhadores, a chave do mistério para solver problemas de legitimação sob uma norma salarial precariamente institucionalizada.

6. As contribuições seminais de Santos (1979), Machado da Silva (1971), mas também de Vianna (1978) e Gomes (1979 e 1994) estão na base das inspirações analíticas de todos os que tentamos enveredar por esse caminho.

7. Agradeço a Luiz Antonio Machado da Silva por ter me chamado a atenção para essa diferença, importante pelo que deixa entrever sobre os mecanismos explanatórios mobilizados por duas gerações de preciosos intérpretes da sociedade brasileira, a dos anos 1960 (como Lopes e Rodrigues) e a dos anos 1970 (como o próprio Machado). Ver igualmente Sader, Paoli e Telles (1983) e Cardoso (2010 e 2010a).

8. Não sem razão o dualismo ou a lógica de tipo funcional deram a régua e o compasso para bem descrever-se tal diferença.

9. Conquanto não seja pretensão deste artigo rever o debate dos economistas brasileiros sobre as características e determinantes dessa mudança, e muito menos resenhar as disjuntivas que os apartaram, chamo atenção para alguns textos recentes, úteis à reflexão dos sociólogos por estabelecerem âncoras factuais importantes. Chahad (2006) tanto quanto Ramos e Ferreira (2005) haviam documentado a contínua queda dos trabalhadores com carteira assinada, revertida, como cedo mostrou Tafner (2006), tanto pelo movimento virtuoso que tem lugar nas regiões metropolitanas (Cavaleri, 2008), como pelo aumento da fiscalização do trabalho, aliada à desburocratização de procedimentos tributários (Simão, 2009), e pelo efeito do crescimento do número médio de empregados nas firmas, que passou a ocorrer até mesmo entre 
as que ingressavam no mercado (Corseuil, Moura e Ramos, 2011). Tais mudanças tiveram lugar num contexto em que o marco regulatório também sofria ajustes, em meio a intensa discussão sobre a necessidade da flexibilização (Krein, 2005).

10. A RAIS (Relação Anual de Informações Sociais) é um registro administrativo produzido pelo Ministério do Trabalho e do Emprego; ela recolhe compulsoriamente, junto às empresas brasileiras, informações sobre contratos firmados ou desfeitos, ao longo de cada ano. A informação permite descrever o perfil dos formalmente contratados em 31 de dezembro de cada ano.

11. A diferença entre o percentual indicado pelo CIEET e o que se obtém via RAIS resulta da metodologia utilizada pela Confederação. Assim, a taxa de participação que se apresenta no Gráfico 4 foi obtida como o quociente entre número de intermediados expresso em unidades de trabalhadores full time e a população ocupada conforme medida pela OIT; para chegar ao numerador desse quociente, que traduz o volume de ocupados pelos intermediadores em "unidades de trabalhadores full time", o CIEET computa o número total de horas trabalhadas pelos empregados através das agências de um mesmo país no período de um ano, e o divide pelo número médio de horas trabalhadas no mesmo período pelos trabalhadores empregados em tempo integral.

12. Aqui há uma ligeira diferença entre o que se mede através da RAIS e da PED. Enquanto a primeira, como dito acima, captura o emprego intermediado tal como informado pelas empresas, a PED tem no indivíduo a sua unidade de informação. O dado deste Gráfico 4 resulta das respostas obtidas para a pergunta: "a pessoa para quem você trabalha é a mesma que lhe paga o salário?" No emprego computado pela RAIS, como vimos, estão todos os envolvidos na atividade de locação de mão de obra, mas também nas de agenciamento e seleção de pessoal.

13. A Rais-Migra é um painel longitudinal, desenvolvido a partir do banco de registros administrativos da RAIS descrito em nota anterior. Utilizando-se do número de identificação do trabalhador nos programas sociais (PIS ou NIS) é possível acompanhar onde o mesmo se localiza no mercado formal de trabalho, em 31 de dezembro e, não estando empregado nessa data, recuperar as informações acerca do seu mais importante contrato de trabalho no ano em apreço. O banco permite, assim, localizá-lo, não importando o setor ou unidade da Federação em que esteja (re)empregado. O identificador permite seguir seu percurso no tempo.

14. Mais detalhes sobre a metodologia de análise fatorial usada para identificar os padrões de percurso descritos nesses achados podem ser obtidos em Guimarães (2009a e 2009b).

15. Agradeço à Fundação SEADE e, em especial, a Vagner Bessa pelo acesso a esses dados e pelo apoio no sentido de bem entender as potencialidades e limites dos mesmos.

16. Conforme documentado em Guimarães (2009a) e Bicev (2010).

17. Agradeço a Álvaro Comin pela sugestão dessa fértil via interpretativa.

18. Agradeço a Machado da Silva por me instigar a ousar nas consequências dessa interpretação, num texto que é certamente tributário das ideias que plantou nos anos 1970 e que repercutirão ainda por muito tempo. 


\section{REFERÊNCIAS BIBLIOGRÁFICAS}

ABRAMO, Lais. (1986), O Resgate da Dignidade. Dissertação de Mestrado, Universidade de São Paul, São Paulo. Posteriormente publicada como L Abramo, (1999), O Resgate da Dignidade: Greve Metalúrgica e Subjetividade Operária. Campinas/São Paulo, Editora da Unicamp/Imprensa Oficial.

ABREU, Alice Rangel de Paiva; GITAHY, Leda; RAMALHO, José Ricardo e RUAS, Roberto. (1998), Reestruturação Produtiva, Trabalho e Educação: Os Efeitos Sociais do Processo de Terceirização em Três Regiões do País. Relatório Final do Projeto. Programa de Pesquisa em Ciência e Tecnologia, Qualificação e Produção. CEDES/FINEP/PCDT-CNPq. Rio de Janeiro.

AGIER, Michel; CASTRO, Nadya A. e GUIMARÃES, Antonio Sérgio. (1995), Imagens e Identidades do Trabalho. São Paulo, Hucitec.

ALMEIDA, Maria Hermínia Tavares de. (1978), “Desarrollo Capitalista y Acción Sindi-

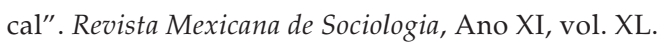

ANTUNES, Ricardo. (1986), A Rebeldia do Trabalho. São Paulo/Campinas, Ensaio/Editora da Unicamp.

AUTOR, David H. (2008), Studies of Labor Market Intermediation. Trabalho apresentado na Conferência sobre Labor Market Intermediation, National Bureau of Economic Research, Chicago, 17-18 de maio.

AUTOR, David e HOUSEMAN, Susan. (2006), Temporary Agency Employment as a Way out of Poverty?. Cambridge, Harvard Inequality Summer Institute, 14-15 de junho.

BERLINCK, Manoel Tosta. (1975), Marginalidade Social e Relações de Classe em São Paulo. Petrópolis, Vozes.

BICEV, Jonas. (2010), Os Trabalhadores Subcontratados da Região Metropolitana de São Paulo. Precariedade ou Estabilização? Dissertação de Mestrado, Programa de Pós-Graduação em Sociologia, Universidade de São Paulo, São Paulo.

BILAC, Elisabete Doria. (1978), Famílias de Trabalhadores. Estratégias de Sobrevivência: A Organização da Vida Familiar em uma Cidade Paulista. São Paulo, Edições Símbolo.

CARDOSO, Adalberto. (2010), “Uma Utopia Brasileira: Vargas e a Construção do Estado de Bem-Estar numa Sociedade Estruturalmente Desigual". DADOS, vol. 53, no 4, pp. 775-819.

. (2010a), A Construção da Sociedade do Trabalho no Brasil. Sociabilidade Capitalista, Padrões de Justiça e Persistência das Desigualdades. Rio de Janeiro, FGV Editora.

_. (2003), A Década Neoliberal e a Crise dos Sindicatos no Brasil. São Paulo, Boitempo. (2000), Trabalhar, Verbo Transitivo. Destinos Profissionais dos Deserdados da Indústria Automobilística. Rio de Janeiro, FGV Editora.

CAVALERI, Rosangela. (2008), “A Expansão da Ocupação em 2007”. Mercado de Trabalho Conjuntura e Análise, no 35. Rio de Janeiro, Ipea.

CHAHAD, José Paulo Z. (2006), “O Emprego Formal no Brasil entre 1992-2006: Comportamento, Tendências Atuais e Causas Explicativas", in J. Macambina (ed.), O Mercado de Trabalho Formal no Brasil. Fortaleza, Imprensa Universitária UFCE. 
CIEET (International Confederation of Private Employment Agencies). (2011), The Agency Industry around the World, Economic Report (based on figures available for 2009). Disponível em http: / / www.ciett.org/index.php?id=163. Acessado em 25 de maio.

. (2010), The Agency Industry around the World, 2010 (based on figures available for 2008. Disponível em http:/ / www.ciett.org/index.php?id=163. Acessado em 25 de maio de 2011.

CORSEUIL, Carlos Henrique; MOURA, Rodrigo e RAMOS, Lauro. (2011), “Determinantes da Expansão do Emprego Formal: O que Explica o Aumento do Tamanho Médio dos Estabelecimentos?". Economia Aplicada, vol. 15, no 1, pp. 45-63.

DIPRETE, Thomas e NONNEMAKER, K. Lynn. (1997), "Structural Change, Labor Market Turbulence, and Labor Market Outcomes". American Sociological Review, vol. 62, no 3, pp. 387-405.

DRUCK, Maria da Graça. (1999), Terceirização: (Des)fordizando a Fábrica. São Paulo, Boitempo.

ELIAS, Peter. (2004), “Reestruturação, Requalificação e Dispensas: Um Estudo da Dinâmica do Mercado de Trabalho do Reino Unido, 1991-95". DADOS, vol. 47, no 3, pp. 419-471.

. (1994), “Occupational Change in a Working-life Perspective: Internal and External Views", in R. Penn, M. Rose e J. Ruberry (eds.), Skill and Occupational Change. Oxford, Oxford University Press, pp. 75-105.

FARIA, Vilmar. (1976), Occupational Marginality, Employment and Poverty in Urban Brazil. Tese de Doutorado. Cambridge, Harvard University Press.

FAUSTO NETO, Ana Maria Quiroga. (1982), Família Operária e Reprodução da Força de Trabalho. Petrópolis, Vozes.

GOMES, Ângela Maria de Castro. (1994), A Invenção do Trabalhismo. Rio de Janeiro, Editora Relume Dumará.

. (1979), Burguesia e Trabalho. Política e legislação social no Brasil 1917-1939. Rio de Janeiro, Editora Campus.

GUIMARÃES, Nadya Araujo. (2009), “A Sociologia dos Mercados de Trabalho, Ontem e Hoje". Novos Estudos Cebrap, no 85.

. (2009a), À Procura de Trabalho. Instituições do Mercado e Redes. Belo Horizonte, Ed. Argvmentvm.

. (2009b), “Trajetórias Surpreendentes: Os Intermediadores de Emprego e seus Trabalhadores", in I. J. Rodrigues; D. Dau e J. Conceição (orgs.), Terceirização no Brasil. Do Discurso da Inovação à Precarização do Trabalho (atualização do debate e perspectivas). São Paulo, Annablume. pp. 49-68.

. (2004), Caminhos Cruzados: Estratégias de empresas e trajetórias de trabalhadores. São Paulo, Ed. 34.

HUMPHREY, John. (1982), Fazendo o Milagre. São Paulo, Vozes/Cebrap.

KOWARICK, Lucio. (1975), Capitalismo e Marginalidade na América Latina. Rio de Janeiro, Paz e Terra. 
LE VEN, Michel. (1983), Processo de Trabalho e Classe Trabalhadora. Trabalho apresentado no VII Encontro Anual da ANPOCS. São Paulo, outubro.

LEITE, Marcia de Paula. (2009), “A Economia Solidária e o Trabalho Associativo: Teorias e Realidades". Revista Brasileira de Ciências Sociais, vol. 24, no 69, pp. 31-51.

(1985), "Reivindicações Sociais dos Metalúrgicos", in M. T. Fleury e R. Fischer (orgs.), Processo e Relações do Trabalho no Brasil. São Paulo, Atlas.

LIMA, Jacob Carlos. (2010), “Participação, Empreendedorismo e Autogestão: Uma Nova Cultura do Trabalho?". Sociologias, vol. 12, no 25, pp. 158-198.

. (2009), "Paradoxos do Trabalho Associado". Tempo Social, vol. 21, no1, pp. 113-132.

. (1996), Trabalho, Mercado e Formação de Classe: Estudo sobre Operários Fabris em Pernambuco. João Pessoa, Editora Universitária da UFPB.

LOPES, Juarez R. Brandão. (1964), Sociedade Industrial no Brasil. São Paulo, Difusão Européia do Livro.

MACHADO DA SILVA, Luiz Antonio. (1991), “A (Des)Organização do Trabalho no Brasil Urbano". São Paulo em Perspectiva. vol. 4, nos. 3/4, pp. 2-5.

(1971), Mercados Metropolitanos de Trabalho Manual e Marginalidade. Dissertação de Mestrado, Programa de Pós-Graduação em Antropologia do Museu Nacional, Universidade Federal do Rio de Janeiro.

MARTINS, Heloisa e RAMALHO, José Ricardo. (1994), Terceirização, Diversidade e Negociação no Mundo do Trabalho. São Paulo, Hucitec.

NORONHA, Eduardo. (2003), “Informal, Ilegal e Injusto: Percepções do Mercado de Trabalho no Brasil". Revista Brasileira de Ciências Sociais, vol. 18, no 53, pp. 112-179.

NUN, José Luis. (1969), “Sobrepoblación Relativa, Ejército Industrial de Reserva y Masa Marginal". Revista Latinoamericana de Sociología, vol. 5, no 2. Republicado em J. Nun. Marginalidad y Exclusión Social. Buenos Aires, Fondo de Cultura Económica (2001), cap. 2 (La teoria de la masa marginal), pp. 35-140.

; MARIN, Juan C. e MURMIS, Miguel. (1967), Planteo general de la marginalidad en América Latina. Santiago, mimeo.

OLIVEIRA, Francisco. (1972), “A Economia Brasileira: Crítica à Razão Dualista”. Estudos Cebrap, no 2 .

PRANDI, José Reginaldo. (1978), O Trabalhador por Conta Própria sob o Capital. São Paulo, Edições Símbolo.

PEREIRA, Luiz. (1965), Trabalho e Desenvolvimento no Brasil. São Paulo, Difusão Européia do Livro.

QUIJANO, Aníbal. (1973), “La Formación de un Universo Marginal en las Ciudades de América Latina", in M. Castells (org.), Imperialismo y Urbanización en América Latina. Barcelona, Gustavo Gili.

. (1967), “Urbanización, Cambio Social y Dependencia”, in F. H. Cardoso e F. Weffort (eds.), América Latina: Ensayos de Interpretación Sociológica. Santiago, Editorial Universitária. 


\section{Nadya Araujo Guimarães}

(1966), Notas sobre el Concepto de Marginalidad Social. Santiago, División de Asuntos Sociales, Cepal, mimeo.

RAMALHO, José Ricardo. (2010), “Flexibilidade e Crise do Emprego Industrial: Sindicatos, Regiões e Novas Ações Empresariais". Sociologias, vol.12, no 25, pp. 252-284. e SANTANA, Marco Aurélio. (2006), “Flexibilidade à Francesa: Trabalhadores na Peugeot Citroën Brasileira”. Tempo Social, vol. 18, no 1, pp. 115-132.

RAMOS, Lauro e FERREIRA, Valéria. (2005), “Padrões Espacial e Setorial da Informalidade no Brasil: 1991-2003". Textos para Discussão, no 1099, IPEA.

RODRIGUES, Iram Jacome; DAU, Denise e CONCEIÇÃO, Jefferson. (2009), Terceirização no Brasil. Do Discurso da Inovação à Precarização do Trabalho (atualização do debate e perspectivas). São Paulo, Annablume.

RODRIGUES, Leôncio Martins. (1970), Industrialização e Atitudes Operárias. São Paulo, Brasiliense.

SADER, Eder; PAOLI, Maria Celia e TELLES, Vera. (1983), "Pensando a Classe Operária: Os Trabalhadores Sujeitos ao Imaginário Acadêmico". Revista Brasileira de História, no 6 .

SANTOS, Wanderley Guilherme dos. (1979), Cidadania e Justiça. Rio de Janeiro, Campus.

SIMÃO, Anna. (2009), Fiscalização do Trabalho e Simplificação Tributária no Brasil Análise de seus Efeitos sobre o Emprego Formal no Período 1999/2007. Dissertação de Mestrado. Rio de Janeiro, UFRJ.

TAFNER, Paulo. (ed.) (2006), Brasil: O Estado de uma Nação. Rio de Janeiro, IPEA.

VIANNA, Luiz Werneck. (1978), Liberalismo e Sindicato no Brasil. Rio de Janeiro, Paz e Terra. 


\begin{abstract}
What Changes with Expansion of the Wage Base (and how can the sociological debate help understand it)?
\end{abstract}

Since the second half of the 2000s, Brazil has witnessed a systematic recovery of formal employment, including an important increase in a special form of job relationship, namely indirect employment. This has led to both the expansion of a new management approach to job recruitment and hiring, plus the consolidation of a burgeoning business segment, with new links between client companies and job agencies. Empirical evidence is used in an in-depth analysis of the situation in São Paulo, Brazil's largest market for both formal jobs and work positions through agencies, drawing on data from the RAIS-Migra and PAEP/SP surveys.

Key words: work market; job agencies; São Paulo; Brazil

\title{
RÉSUMÉ
}

Ce qui Change Lorsqu'on Élargit le Salariat (et en quoi le débat en Sociologie peut-il nous aider à le comprendre?)

Depuis la seconde moitié des années 2000, on observe au Brésil une reprise continue de l'emploi formel comprenant la croissance remarquable d'une forme particulière de relation d'emploi, c'est-à-dire le travail par intermédiation. On élargit ainsi non seulement une autre modalité de gestion de l'embauche et des contrats de travail, mais on renforce un florissant domaine des affaires d'où émergent de nouvelles formes d'articulation entre sociétés usagères et médiatrices du travail. Des preuves empiriques approfondissent le cas de São Paulo, le plus grand marché brésilien d'emplois formels, ainsi que de postes par intermédiation, selon des données de la RAIS-Migra et de la PAEP/SP.

Mots-clés: marché du travail; intermédiation de l'emploi; São Paulo; Brésil 